LAERE MIDDEL ODK

\title{
Virksomhedsformer og teknologibegre- ber fra læseplan til praksis i og på tværs af tre fag
}

Af Lone Nielsen, Dorte Moeskær Larsen, Helle Kruse Krossá \& Morten Rask Petersen 
Formålet med denne artikel er at se på, hvorledes teknologiforståelse kommer til udtryk som en integreret del af fag både i styredokumenter for forsøgsfagligheden og i praksis gennem et multiple case studie med fokus på fagene dansk, matematik og natur/teknologi i folkeskolens mellemtrin. Casestudierne er lavet inden for rammen af et større projekt kaldet Børnene i robotbyen. Hver case indeholder undersøgelser af, hvorledes styredokumenter lægger op til arbejdet med teknologiforståelse integreret i fagene, og hvilket teknologiforståelsesbegreb der anvendes samt empiriske undersøgelser af, hvorledes dette ser ud i praksis. Resultaterne viser, at der i styredokumenter er en forholdsvis snæver og analytisk tilgang til teknologiforståelse, mens praksis er mere nuanceret. Dette diskuteres i forhold til og på tværs af de enkelte fag.

Technology understanding and teachers' work with this, is timely in the Danish folkeskole. Currently, there are explorations of technology understanding both as individual topics and as integrated in existing topics. This article examines how technology understanding is expressed as integrated in the existing topics in both steering documents and in practice. We do so through a multiple case study within the subjects Danish, Mathematics, and Nature/Technology. The case studies was framed within the larger project The Children in the Robotic City. Each case is analysed based on how steering documents describe the work with technology understanding and which underlying concept of technology this builds on. This is compared to how it is enacted in practice. The findings show that the steering documents have a narrow and analytical expression of technology understanding while practice is more nuanced. The findings are discussed across the subjects and in relation to traditions within the subjects. 


\section{Virksomhedsformer}

og teknologibegreber fra læseplan til praksis i og på tværs af tre fag

\section{Indledning}

I disse år udvikles og afprøves en ny faglighed i folkeskolen ved navn Teknologiforståelse. Denne artikel vil komme med perspektiver på "teknologiforståelsens fagdidaktik". Det vil være med udgangspunkt i empiri fra et forskning- og udviklingsprojekt, hvor fagformålstekster, fælles mål for forsøgsfaget integreret i tre forskellige fag og tilføjelser til læseplaner er blevet forsøgt oversat og anvendt i praksis. I undervisningens praksis såvel som i retorikken om fagligheden forbindes fagteori og didaktik gennem diskursiv og kommunikativ praksis. Den diskursive praksis for teknologiforståelsens fagdidaktik, og det at forstå digital teknologi og dens konsekvenser for os mennesker som fagligt område eller domæne, rækker langt tilbage (eksempelvis Naur, 1954). Der har, de sidste 50 år, med varieret styrke været forsøg på at få et fag - eksempelvis datalære - med dette som genstandsfelt ind i grundskolen (Caeli \& Bundsgaard, 2019).

I december 2018 blev Fælles Mål og fagformål for forsøgsfagligheden Teknologiforståelse offentliggjort med de fire kompetenceområder: digital myndiggørelse, computationel tankegang, digital design og designprocesser samt teknologisk handleevne (Børne- og Undervisningsministeriet, 2019). Samme år satte undervisningsministeriet et treårigt afprøvningsforsøg i gang på 46 danske grundskoler, hvis formål er at afprøve den nye faglighed. Begrebet teknologiforståelse betegner altså en forsøgsfaglighed, som er formuleret på kort tid.

Ud over det selvstændige teknologiforståelsesfag er teknologiforståelsesfagligheden også integreret i syv skolefag i forsøgsprojektet. Her er opdraget, at teknologiforståelsesfagligheden introducerer nye perspektiver på den eksisterende faglighed ved, at mål fra teknologi- 
forståelse som fag er blevet skrevet ind i de eksisterende fælles mål for fagene (Undervisningsministeriet, 2018b, s. 6). Fortolkningen af den nye faglighed er i forsøgsprojektet præget af en række toneangivende eksperter med viden om især science, teknologi og designtænkning (Dindler, Smith \& Iversen, 2019; Caspersen, Iversen, Nielsen, Hjorth \& Musaeus, 2018).

Undervejs i forsøgsprojektperioden er den nye faglighed, som den er beskrevet i forsøgsprojektet, blevet både problematiseret, kritiseret og diskuteret fra flere sider og med forskellige stemmer i en række forskellige artikler og medier (eksempelvis Unge Pædagoger, KVAN, Altinget og Folkeskolen.dk). Eksempelvis problematiseres fagets begreb om myndiggørelse det, at faget har fokus på "digital teknologi" og negligerer teknologifilosofi og teknologihistorie (Christensen, 2021; Fibiger, Hjorth, Lorentzen \& Pasgaard, 2019), ligesom designbegrebet og designtilgangen problematiseres, og der med udgangspunkt i tankerne om spekulativt design blandt andet kaldes på en udvidelse af det instrumentelle designbegreb (Nørgård, 2020). Som en del af debatten efterlyses også grundlagsdiskussioner af fagligheden, fokus på teknologi som fænomen, som brug, som historisk og sociokulturelt artefakt og som del af et større samfundsmæssigt problemkompleks (Rasch-Christensen \& Hansen, 2021), og der kaldes blandt andet mere bredt på en kritisk teknologiforståelse, der ikke vægter digitale teknologier (Balslev, Riis \& Hasse, 2021). Denne nationale diskussion trækker på beslægtede internationale tendenser (eksempelvis Ihde, 2002; Balsamo, 2005, 2011; Dakers, 2006, 2014).

Ovenstående beskrivelse af de offentlige diskussioner viser, at måden, man taler om et fag, kan ændre sig hurtigt. Det diskursive niveau i faghæfter og faglige debatter har en hurtigere forandringshastighed end måden, man praktiserer faget og fagligheden på og især hurtigere end den viden, man bygger det på (Krogh, 2011).

I denne artikel vil vi undersøge fagdidaktiske ytringer om teknologiforståelse i mødet med tre eksisterende fag, som vi møder dem i fagenes didaktiseringsprocesser fra de diskursive ministerielle styredokumenter for forsøgsprojektet i henholdsvis natur \& teknologi, matematik og dansk og til praksis for eleverne i konkrete praksisforløb i de tre fag. Dette med henblik på at undersøge, hvordan teknologiforståelsesfagligt indhold forestilles integreret og integreres i eksisterende fag. Samtidig undersøger vi, om der er eventuelle ens mønstre på tværs af fag, eller om fagene har en særegen tilgang til teknologiforståelse. 
Udgangspunktet for denne undersøgelse er forskningsspørgsmålet:

Hvorledes kommer teknologibegreber og arbejdet med disse til udtryk i styredokumenter og i praksis både i fag og på tværs af fag?

Vi vil først, efter både et teoretisk og et metodisk afsnit, undersøge hvilke virksomhedsformer der kommer til udtryk først i styredokumenter og derefter i en undervisningspraksis. Dernæst vil vi unders $\emptyset$ ge, hvilke teknologibegreber der lægges op til i først styredokumenter og derefter i praksis. Begge afsnit afsluttes med en refleksion og diskussion over sammenhængen mellem både styredokument og praksis og fagene imellem.

\section{Teknologibegreber i en flerdimensionel teknologiforståelse}

Forestillingen om hvilket indhold, der er i en teknologiforståelsesfaglighed, har været diskuteret bredt nationalt (se for eksempel Hansen, 2020c, og Christensen, 2020). Internationalt er der et bredt felt med fortalere for en teknologisk uddannelse, der er teknisk, empirisk og regelstyret, og som tjener industriens behov, mens andre er fortalere for en teknologisk uddannelse, der er hermeneutisk, fortolkende og akademisk (Dakers, 2006).

For at sætte rammen om en flerdimensionel teknologiforståelse og forskningsspørgsmålets begreb "teknologibegreber", vil vi pege på flere forskellige vigtige perspektiver i den internationale diskurs: Balsamo (2005) understreger vigtigheden af, at blandt andet humanister, kunstnere og samfundsvidenskab også får en stemme i dette og anvender begrebet teknologisk "imagination", idet han mener, at kilden til teknologisk innovation er den teknologiske fantasi, en sindskvalitet, der sætter folk i stand til at tænke med teknologi for at omdanne det kendte til det mulige (Balsamo, 2005, 2011). Dette inkluderer undervisning både i kritiske måder at evaluere teknologi på og kreative og metodiske anvendelser af teknologiske værktøjer. Selwyn (2010) foreslår overordnet også en bred tilgang til teknologisk "imagination" med mere fokus på demokrati og social retfærdighed og foreslår samtidig, at der skal være mere fokus på hvorfor end hvordan. Det handler ikke kun om at reproducere verden, som vi allerede kender den, men om 
at kunne bidrage til at overskride, udvikle og forbedre den. Med fokus på teknologiens kulturforandrende kraft understreger Dakers (2006), at 'teknologiforståelse' ikke alene kan knyttes til en STEM-baseret opfattelse af, hvad teknologi er, og hvordan den virker i verden (Dakers, 2014). Dakers argumenterer for eksempel for, at der er behov for et bredere perspektiv på uddannelse i teknologiforståelse og en mere kritisk orienteret form for viden om teknologi. Disse forestillinger om indhold i teknologiforståelsesfagligheden afhænger naturligt af, at der er forskellige videnskabsteoretiske måder at forholde sig til teknologi på (Dakers, 2006; Tamborg, Dreyøe \& Fought, 2018). Det er et bredt felt, der ligesom andre fagfelter er præget af divergenser, forandringer og løbende definitionskampe. Forstår man eksempelvis teknologi som instrumenter, mennesker kan gøre noget med, eller tillægger man teknologien en selvstændig værdi og agens. Eller forstår man teknologi fra et sociokulturelt eller fænomenologisk niveau og er nysgerrig på, hvordan teknologi eksisterer i verden eller hvordan mennesker eksisterer i verden med teknologi (Heidegger, 1999; Ihde, 1998).

Når vi i artiklen begrebsætter teknologibegreber, er det ud fra tankerne om en flerdimensionel teknologiforståelse, hvor vi med Hansens syv måder at begrebsliggøre teknologi på (Hansen, 2020c), reducerer ovenstående kompleksitet ved at spørge mere konkret til teknologi som didaktisk anledning til undervisning i skolen.

Hansens syv teknologibegreber er:

i) det instrumentelle teknologibegreb, der omhandler, hvad teknologien gør for os,

ii) det antropologiske teknologibegreb, der fokuserer på, hvad teknologien gør ved os,

iii) det humanistiske teknologibegreb, om hvordan vi forstår teknologien i etisk, æstetisk og historisk perspektiv, hvad betyder den æstetisk-historiske forestillingsevne for den teknologiske udvikling og omvendt,

iv) det naturvidenskabelige teknologibegreb, om hvordan teknikken i teknologien virker,

v) det didaktiske teknologibegreb, i forhold til, hvad teknologien betyder for fag og undervisning,

vi) det sociologiske teknologibegreb, der fokuserer på teknologiens betydning for vores samfund samt

vii) det politiske teknologibegreb, der omhandler holdninger og reguleringer af teknologi (Hansen, 2020c). 


\section{Virksomhedsformer}

Ud over indholdet i teknologiforståelsesfagligheden og teknologibegreberne er måden, eleverne arbejder på, også central. Hansen (2020a) argumenterer for, at et alsidigt og varieret forløb i teknologiforståelse typisk vil kombinere forskellige virksomhedsformer.

Teorien om virksomhedsformer har sit videnskabsteoretiske ståsted med inspiration fra forskellige traditioner som Kant, Husserl, Dewey og Habermas. Teorien beskriver og inddeler handlinger og undervisningsmønstre ud fra forskellige måder at være virksom på (Brodersen, 1988). Virksomhedsformerne handler således om, hvordan et indhold bringes i spil i undervisningen, og hvad indholdet skal bruges til. Teorien er videreudviklet fra oprindeligt 5 virksomhedsformer (se for eksempel Schnedler \& Seeberg, 1998) i Brodersen, Hansen \& Ziehe (2019), der argumenterer for en reduktion til fire virksomhedsformer, nemlig:

1) den æstetiske virksomhedsform, forstået som en kropslig og sanselig form. (oplevelser og udtryk)

2) den analytiske virksomhedsform, hvor fagsproget anvendes til at nedbryde helheder i mindre dele. (analyse og demonstration)

3) den håndværksmæssige virksomhedsform, som kræver fagspecifikke færdigheder. (iagttagelse og træning)

4) den kommunikative virksomhedsform, hvor der er tale om aktiv deltagelse både som modtager og afsender i kommunikation med andre. (modtagelse og fremstilling)

Virksomhedsformerne har både en receptiv og en produktiv dimension (parenteserne ovenfor) samt en refleksiv dimension. Disse fire virksomhedsformer komplementerer hinanden, hvor der på den ene side er et spænd mellem affektive (æstetisk) og kognitive (analytisk) virksomhedsformer og på den anden side et spænd mellem udøvende (håndværksmæssige) og formidlende (kommunikative).

\section{Børnene i robotbyen på fire faglige udviklings- skoler (BIR)}

Konteksten for undersøgelserne er BIR-projektet, som er et samarbejdskoncept mellem Odense Kommune og UCL Professionshøjskole og Erhvervsakademi. Projektet er en del af Odense Kommunes strategi om Verdens bedste Robotby ${ }^{1}$.

1 https://www.odense.dk/verdensbedsterobotbyiboernehoejde/ boernene-i-robotbyen Lokaliseret 17/3 2021 
I projektet har lærere på fire udvalgte skoler i samarbejde med læreruddannere udviklet, afprøvet og evalueret undervisningsforløb i udvalgte klasser på mellemtrinnet i såvel STEM-fagene; matematik og natur/teknologi, som de humanistiske og kunstneriske fag; dansk og håndværk \& design.

Udviklingen af undervisningsforløbene har bygget på de nye Fælles Mål og læseplaner for forsøgsprojektet omkring teknologiforståelse i fag, og har samtidig taget afsæt i og er blevet formet af scenariet omkring børnene i robotbyen, hvor "byen" og "robotter" i alle forløb bidrager til at skabe et scenariedidaktiskperspektiv (Hanghøj, Misfeldt, Bundsgaard, Fougt \& Hetmar, 2017). Robotter forstås her bredt som alle former for "digitale slaver" og er dermed ikke bundet til en særlig materialitet.

Således har der i hvert forløb pågået:

— En udvikling af forløb i samarbejde mellem en læreruddanner og en lærer med afsæt i lærerens egen planlægning.

— Observation af den planlagte undervisning og efterbearbejdning.

— Evaluering af forløbet og en beskrivelse af undervisningsforløbet til brug for andre.

Grundet COVID-19-restriktioner blev alle forløb desværre ikke afprøvet i praksis. I denne artikel vil vi derfor kun forholde os til forløb fra fagene matematik (4. klasse), dansk (5. klasse) samt natur/teknologi (5. klasse). Dette gøres først ved at se på styredokumenterne fra de enkelte fag og dernæst på den praktiske udførsel af forløbene i fagene.

\section{Metodisk tilgang}

Idet vi i denne undersøgelse arbejder med et spænd fra styredokumenter til praktisk undervisning bliver datamaterialet for undersøgelsen meget uens. Der er derfor brug for at anvende forskellige metoder til de forskellige former for data.

Forskningsdesignet er baseret på et kvalitativt, multiple casestudie (Flyvbjerg, 2006; Stake, 2013), hvor tre cases er udvalgt fra projekt "Børnene i robotbyen". De tre cases er udviklede og afprøvede undervisningsforløb med teknologiforståelse i matematik, i dansk og i natur/teknologi på mellemtrinnet. Hver case består af en analyse af styredokumenter for det respektive fag og tilhørende trinniveau samt en undersøgelse af praksis i de enkelte fag. 


\section{Analyse af styredokumenter}

Styredokumenternes mål og tilføjelser til læseplanen om teknologiforståelse i hhv. dansk, matematik og natur/teknologi er analyseret gennem en målrettet kvalitativ indholdsanalyse (Hsieh \& Shannon, 2005). Koderne er de fire virksomhedsformer. Målet med denne analyse er at finde frem til hvilke virksomhedsformer, der lægges op til gennem læseplanerne. For at kompleksitetsreducere kodningen blev der lavet én kodning for hvert beskrevet mål i læseplanen. Hvert mål indeholder alle en understående beskrivelse, hvor der lægges op til og kommes med forslag til forskellige virksomhedsformer. For at kunne identificere virksomhedsformerne blev der af fire forskere udarbejdet en operationaliseringsguide til hver af de fire virksomhedsformer (Appendix).

For at kunne kategorisere graden af tilstedeværelse for de enkelte virksomhedsformer blev der udviklet en kodningskategori (se Appendix).

Hver læseplan er kodet af 2 uafhængige forskere, hvorefter der blev udført en test for inter-koder reliabilitet (Cohen’s қ). Testen viste acceptable til stærke sammenfald i kodningerne (dansk ${ }_{\beta}=0,60$, mate-

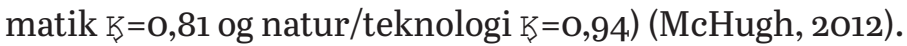

Læseplanerne er ligeledes blevet kodet for hvilke teknologibegreber, der anvendes. Her er udgangspunktet de syv teknologibegreber fra Hansen (2020c). I undersøgelsen af teknologibegreber blev der fokuseret på tilstedeværelsen af teknologibegreberne. Læseplanerne blev gennemlæst og diskuteret i forskergruppen for at skabe en konsensusanalyse af teknologibegreber i teksterne.

\section{Undervisningspraksis}

Undervisningsforløbene havde hver et omfang af ca. 6 - 9 lektioner. I hvert forløb blev undervisningen videooptaget ud fra en ikke-deltagende tilgang (Fangen, 2010). Der blev oprettet en observationsmanual. Målet var, at kameraet skulle følge elevernes gruppearbejde, samt læreren, når der var oplæg eller beskeder til klassen.

Hver observation blev grovtransskriberet (Matthews \& Cramer, 2008) hvor lektionernes indhold blev beskrevet i kronologisk rækkefølge med tidsangivelser og opgaveformuleringer og enkelte citater.

Efterfølgende blev grovtransskriptionerne kodet ud fra de 4 virksomhedsformer (Hansen, 2020a). Der blev nedskrevet en kode for hver gang, der i undervisningen og dermed også gruppearbejdet, var et skifte mellem de receptive og produktive faser. Når der har været identificeret mere end én virksomhedsform til stede under samme aktivitet, er begge virksomhedsformer blevet noteret. På baggrund af dette er der foretaget en deskriptiv analyse af hvert forløb, hvor de 
identificerede virksomhedsformer præsenteres i beskrivelsen af den enkelte case. Ligeledes er grovtranskriptionerne blevet analyseret for hvilke teknologibegreber, der kommer i anvendelse i undervisningen.

\section{Analyse af virksomhedsformer i styredokumenter}

Første skridt i undersøgelsen af de enkelte fag er en analyse af, hvorledes de centrale styredokumenter beskriver måder at arbejde med teknologi på. Analysen vil ikke kunne give et samlet billede af, hvordan teknologiforståelse tænkes ind i skolen, men udelukkende et billede af, hvordan det tænkes ind i undersøgelsens tre fag på mellemtrinnet. Dokumentanalysen er blevet afgrænset til kun at omhandle tilføjelserne til læseplanerne til forsøgsprogrammet med teknologiforståelse (Undervisningsministeriet, 2018b,c,d) i de tre fag.

I Tabel 1 ses kodningen for alle tre fag i denne undersøgelse.

\section{Tabel 1.}

Kodning af læseplanerne for teknologiforståelse integreret i de enkelte fag i forhold til virksomhedsformer. Kodningerne er udelukkede foretaget for mellemtrinnet.

Hvor der har været uoverensstemmelse mellem koderne er begge koder angivet med /

\begin{tabular}{|c|c|c|c|c|}
\hline \multirow[t]{2}{*}{ Fag } & \multicolumn{4}{|c|}{ Virksomhedsform } \\
\hline & Kommunikativ & Analytisk & Estetisk & Håndværksmæssig \\
\hline \multicolumn{5}{|l|}{ Dansk } \\
\hline 1.a Digitalt design & 0 & 3 & 0 & 0 \\
\hline 1.b Digitalt design & $2 / 3$ & $0 / 2$ & 0 & 0 \\
\hline $\begin{array}{l}\text { 2.a Digital } \\
\text { myndiggørelse }\end{array}$ & $0 / 1$ & $2 / 3$ & $0 / 1$ & 0 \\
\hline $\begin{array}{l}\text { 2.b Digital } \\
\text { myndiggørelse }\end{array}$ & $1 / 2$ & 2 & $0 / 1$ & 0 \\
\hline 3 Digital sikkerhed & 0 & $2 / 3$ & 0 & $0 / 1$ \\
\hline
\end{tabular}




\begin{tabular}{|c|c|c|c|c|}
\hline Matematik & & & & \\
\hline $\begin{array}{l}\text { Digital design og } \\
\text { designprocesser }\end{array}$ & 1 & 2 & 1 & 0 \\
\hline Modellering & $0 / 1$ & 2 & 0 & $0 / 1$ \\
\hline Programmering & 1 & 2 & $0 / 1$ & 0 \\
\hline $\begin{array}{l}\text { Data algoritmer og } \\
\text { strukturering }\end{array}$ & $0 / 1$ & 2 & 1 & 0 \\
\hline $\begin{array}{l}\text { Brugerstudier og } \\
\text { redesign }\end{array}$ & $0 / 1$ & 2 & 1 & 0 \\
\hline \multicolumn{5}{|l|}{ Natur/Teknologi } \\
\hline Undersøgelse & 0 & 3 & 0 & 0 \\
\hline Modellering & 1 & 2 & 0 & 0 \\
\hline Perspektivering & 1 & 2 & 0 & 0 \\
\hline Kommunikation & 2 & 2 & $0 / 1$ & 0 \\
\hline
\end{tabular}

På trods af forskellene imellem måderne hvorpå teknologiforståelsesfagligheden er indskrevet i de tre fag ses det, at den håndværksmæssige virksomhedsform er fraværende i alle tre læseplaner. Således vægtes øvelse og specialisering ikke eksplicit i de mål og efterfølgende tekster i tillæggene til de tre fags læseplaner på mellemtrinnet.

Det er også påfaldende, at den æstetiske virksomhedsform er mest repræsenteret i matematikfaget (2-3 koder). Umiddelbart kunne overskriften i færdigheds-/vidensområdet Digitalt design og designprocesser i danskfagets tillæg til læseplanen bringe forestillinger i retning af en æstetisk virksomhedsform, der knytter sig til skabende udtryk. Men i de konkrete mål og den konkretiserende tekst vægtes den analytiske virksomhedsform med et fokus på en elementorienteret analyse/undersøgelse af problemfelter.

Det samlede billede for de tre fags integration af teknologiforståelsesfagligheden på mellemtrinnet er forholdsvis entydigt, da der i høj grad lægges op til en analytisk og til dels kommunikativ virksomhed for eleverne. Vi ser dermed, på tværs af de tre fags tillæg til læseplanerne på mellemtrinnet, et fokus på elementorienteret analyse og kommunikation om indhold i et fællesskab. 


\section{Idégenereringsfase}

Den første del af figuren viser den idégenererende fase, hvor eleverne startede i en æstetisk virksomhedsform. De kunne her give udtryk for deres egne fantasier og forestillinger og inddrage flere sanser. Eleverne havde mange forskellige idéer - lige fra et egern der juleshopper til julemænd, der bliver kørt ned. Undervejs i den idégenerede proces skulle eleverne først nedskrive deres idéer og fremlægge disse for hinanden. Den idégenerende fase afsluttedes med, at grupperne skulle fremlægge deres idéer for hele klassen i en kommunikativ virksomhedsform. Kommunikationen blev i denne fase brugt både som udtryksmiddel, som et refleksionsværktøj og som adgang til andres forståelser (Se Figur 1, idégenereringsfase).

\section{Produktivfase}

Den produktive del af forløbet er forløbets vægtigste del. Her observerede vi en vekslen mellem alle fire virksomhedsformer. Efter den idégenererende fase startede eleverne med at gå ind i programmet Scratch. De havde tidligere arbejdet lidt med programmet i håndværk og design og gik straks i gang med at udvikle deres baggrunde og deres sprites (figurerne i programmet). I denne proces var eleverne igen i den æstetiske virksomhedsform, da de arbejdede med sansekonkrete fænomener - hvordan ser en julemand ud, der bliver kørt ned? Skal der være lyde og så videre? Eleverne indgik både i en receptiv og en produktiv dimension af den æstetiske virksomhedsform, da de afprøvede muligheder i programmet (se Figur 1, produktiv fase).

Herefter skulle eleverne få figurerne til at bevæge sig i Scratch. Dette var nyt for dem. Deres lærer valgte her at gå ud af programmet og starte i matematikkens verden med en repetition af koordinatsystemets opbygning. Hun gav eleverne enkelte opgaver omkring koordinatsæt. Eleverne var her i en håndværksmæssig virksomhedsform, da de arbejdede med afgrænsede små øvelser (se Figur 1, produktiv fase).

Da eleverne efterfølgende gik ind i programmet Scratch, arbejdede de først analytisk med, hvordan de fik figurerne til at bevæge sig rundt i koordinatsystemet. Dette blev efterfulgt af bestemte typer af programmeringssekvenser. Eleverne bevægede sig nu imellem den håndværksmæssige virksomhedsform og den analytiske virksomhedsform, hvor det både handlede om at forstå de forskellige koder, og at få en vis færdighed i at anvende koderne. Eleverne bevægede sig således imellem både en receptiv og skabende dimension i de to virksomhedsformer (se Figur 1, produktiv fase).

Eleverne gik derefter tilbage til deres egne scratchfilm, hvor de fik til opgave, at deres videoer skulle indeholde bevægelser af deres sprites, skift af baggrund, kloninger og talebobler. En gruppe ville ek- 
sempelvis have to jule-egern til at bevæge sig rundt på et værelse, mens de talte sammen efterfulgt af et snevejr udenfor. I denne programmeringsfase vekslede eleverne mellem den analytiske virksomhedsform, ved at anvende deres forståelser for kodning til at få udarbejdet de forskellige bevægelser, men var samtidig i den æstetisk virksomhedsform, fordi de var opmærksomme på, at deres film blev æstetisk flot (se Figur 1, produktiv fase). Læreren afbrød ind imellem elevernes arbejdsproces i denne fase, både for at give gode råd undervejs i processen og for at demonstrere forskellige kommandoer i Scratch. Eleverne kom i disse situationer i en kommunikativ virksomhedsform, idet de her skulle lytte aktivt og være modtagerne. Samtidig foregik det meste arbejde i denne fase i grupper. Det betød, at de løbende indgik i den kommunikative virksomhedsform i de dialogbaserede opgaver. På Figur 1 kan det ses, at disse virksomhedsformer blev gentaget i flere omgange (se Figur 1, afslutningen af den produktive fase).

\section{Proesentationsfasen}

I sidste fase med fremlæggelse af produktet var eleverne både i en receptiv og skabende dimension af den kommunikative virksomhedsform, idet eleverne i grupper både skulle fremvise deres video, se og lytte til fremlæggelserne og give feedback til andre grupper (se Figur 1, præsentationsfasen).

\section{Virksomhedsformer $i$ et dansk-teknologifagligt forløb om chat- bots}

I danskforløbet skulle eleverne udvikle en chatbot, som de forestillede sig kunne bruges til at hjælpe nye elever tilpas på skolen. Forløbet blev planlagt, så eleverne levede sig ind i situationen at være ny på skolen, og i forlængelse heraf overvejede, hvor en robot kunne erstatte et menneske i den proces. Undervejs i forløbet var det planlagt, at eleverne både skulle eksperimentere med, analysere og selv skabe en chatbot i iterative designprocesser.

Forløbet tog udgangspunkt i det teknologifaglige fænomen "robot" et sted, hvor "robotter" er integreret i den private og sproglige sfære, og ikke bare udfører praktiske opgaver for mennesker. Formålet var at sætte mennesket i centrum og teknologierne til kritisk debat, og dermed udfordre eleverne på det etiske og erkendelsesteoretiske plan. For hvis man kan bruge en robot som den første ven på en ny skole, hvad vil det så sige at være menneske?

I forløbet arbejdedes der med to danskfaglige kompetenceområder: fremstilling og kommunikation, ligesom forløbet havde fokus på digitalt design og designprocesser samt digital myndiggørelse fra det teknologifaglige område. Forløbet blev planlagt i tre faser med en 
introducerende del, en mere undersøgende/eksperimenterende del, hvor eleverne i iterative processer skulle designe forskellige bud på en chatbot, som kan hjælpe nye elever på skolen. De forskellige bud på chatbots skulle i forløbets sidste fase præsenteres for skoleledelsen og evt. elevrådet og skolebestyrelse. Desværre blev kun introfasen gennemført og dermed observeret, og nedenstående model er et overblik over virksomhedsformerne i forbindelse med aktiviteterne i forløbets første fase, som tidsmæssigt strakte sig over seks lektioner.

Som modellen over forløbets introfase viser, observerede vi en produktiv rytme og vekselvirkning i undervisningen mellem æstetisk oplevelse, indlevelse og udtryk på den ene side og analytisk distance og refleksion på den anden.

Figur 2.

En tidslig analyse af de forskellige virksomhedsformer i danskforløbet.

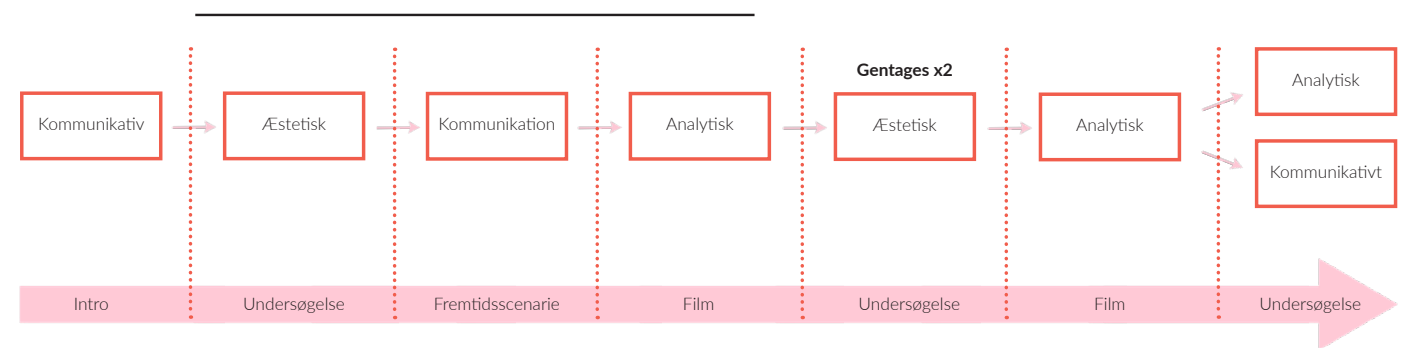

\section{Introfasen}

I introfasen var fokus på, at eleverne skulle introduceres til scenariet og bygge bro mellem deres forforståelser af begrebet robot og den chatbot, de skulle lave. Konkret fortæller læreren i denne fase blandt andet eleverne:

99 Vi er nysgerrige på, hvad I tænker en robot er. Vi skal samle 100vis af billeder af forskellige slags og typer robotter.

(Dansk 5. kl., introfase)

\section{Undersøgelse-ogfremtidscenarie-faserne}

Efter introfasen sendes eleverne i grupper for at finde billeder af robotter og diskutere, hvad de mener en robot er. Vi observerede her, at den æstetiske virksomhedsform blev tildelt en helt central rolle, hvorfra man kan sige, at forløbet udsprang. Eleverne skulle dels sanse 
og føle gennem en undersøgelse af billeder af hundredvis af robotter, som de fandt på nettet, og som skulle danne udgangspunkt for deres produktion af klassens fælles æstetiske udtryk, en billedcollage. Her gav eleverne udtryk for deres egne fantasier og forestillinger om robotter og chatbots (se Figur 2, undersøgelsesfasen).

\section{Film-og undersøgelsesfaserne}

Ud over undersøgelsen af begrebet robot og billedcollagen fik eleverne indtryk fra to små film, hvor robotter spiller en central og overraskende rolle (se Figur 2, filmfaserne).

I vekselvirkning med den æstetiske virksomhedsform, så arbejdedes der også med analytiske forholdemåder, hvor hensigten var, at eleverne, på baggrund af deres sansekonkrete oplevelser med film, billeder og collager, skulle arbejde begrebsligt og forankret i sprog med at bestemme, beskrive og forklare egenskaber ved fænomenet "robot" og forsøge at kategorisere dette sammen med klassekammeraterne. I den gruppe som kameraret fulgte, var dialogen om begrebet "robot" minimal. En af gruppens elever foreslog denne definition, som resten af gruppen indvilligede i: En robot skal voere klog og stoerk til at hjoelpe med vores hårde arbejde. De kan også hjoelpe os med praktiske pligter (Dansk 5. kl., undersøgelsesfase).

Da læreren initierede en opsamling af gruppearbejdet var den kommunikative virksomhed både dialogisk undersøgende. Fra de enkelte grupper fremkom bud, der understøttede og udfordrede hinanden - for eksempel på lærerens spørgsmål om, hvad en robot kan:

\section{Dreng 1: Den kanfx levere mad}

Pige 1: Den kan blive brugt til at hjoelpe folk ud af brondende huse

Pige 2: Den kan støvsuge, køre biler uden fører, slå groes

Dreng 2: Den kan gøre arbejdet lettere for mennesker

Dreng 3: Og de kan bruges til at erstatte loereren - ha, ha

(Dansk 5. kl., undersøgelsesfasen)

Den kommunikative virksomhedsform var også dialogisk holdningsorienteret, hvor eleverne argumenterede og begrundede holdninger og værdier i forhold til, hvad robotter kan bruges til og erstatte, og hvad de ikke kan erstatte. Det blev for eksempel debatteret, hvorvidt en lærer kan erstattes af en robot (se Figur 2, undersøgelsesfaserne).

I forbindelse med planlægningen af resten af forløbet var det intenderet, at mønsteret med at lade arbejdet i den æstetiske virksomhedsform danne udgangspunkt for resten af forløbets faser, fortsatte. Dette i en vekselvirkning mellem den analytiske og den kommunikative virksomhedsform. 


\section{Virksomhedsformer i et natur/teknologiforløb om køkkenhaver}

Forløbet i natur/teknologi tager udgangspunkt i, at klasserne i foråret skal lave køkkenhaver og i samarbejde med madkundskab og matematik dyrke afgrøder der. I forløbet er der fokus på, at eleverne skal designe et system til at passe planterne for eksempel i forhold til lys og fugtighed.

Formålet med forløbet var et scenarie så virkelighedsnært som muligt, der kunne relateres til skolens profil som verdensmålsskole. I forhold til det teknologiforståelsesfaglige var målet, at eleverne gennem en designtilgang opnåede programmeringsfærdigheder og en forståelse for dataindsamling ved hjælp af sensorer. Inden for teknologiforståelsesfagets kompetencer var der særligt fokus på design og designprocessor, hvor der i natur/teknologifaget var fokus på færdigheds og vidensmålene: 'Eleven kan udvikle enkle produkter' og 'Eleven kan identificere ressourcebesparende teknologier' (Børne- og Undervisningsministeriet, 2020).

Figuren illustrerer virksomhedsformerne i forløbet, der i høj grad var præget af en vekslen mellem kommunikative og analytiske virksomhedsformer. Den æstetiske virksomhedsform knytter sig til en særskilt aktivitet i forløbet, mens den håndværksmæssige virksomhedsform ses som nødvendig for elever, der er uerfarne med at tilslutte og programmere.

Figur 3.

En tidslig analyse af de forskellige virksomhedsformer i forløbet Natur/teknologi.

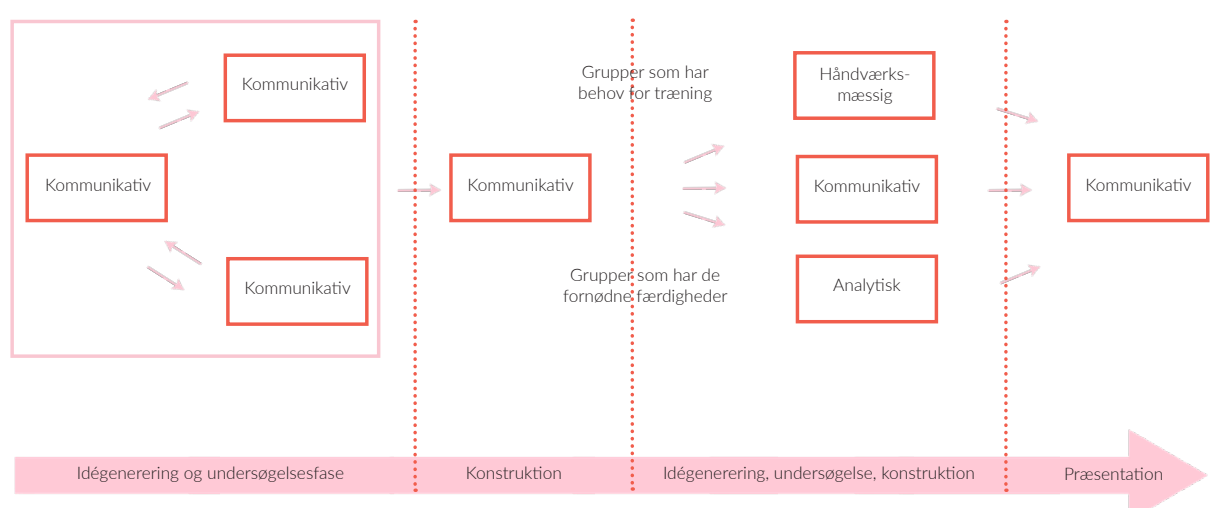




\section{Undersøgelses- og idégenereringsfasen}

Figuren illustrerer, at eleverne som det første gik i gang med unders $\emptyset$ gelses- og idégenereringsfasen, hvor de skulle ud og måle køkkenhaven op, undersøge hvor højbedene skulle stå og observere på havens placering i forhold til solen. En gruppe var udfordrede af, at virkeligheden ikke er så pæn som i teorien. Pladsen var ikke helt rektangulær, og de diskuterede længe, hvordan de så skulle måle pladsen, men i fællesskab fandt de en løsning. Derefter gik eleverne i klassen og tegnede køkkenhaven op i en passende målestok og placerede højbedene på tegningen. Eleverne arbejdede med opgaven gennem den analytiske virksomhedsform, men også meget kommunikativt, da de i grupper hele tiden diskuterede de valg og metoder, som de tog undervejs. Der var i denne fase vekselvirkning mellem det receptive, hvor læreren stiller spørgsmål og nye opgaver og det produktive, hvor eleverne diskuterede sig frem til en løsning (se Figur 3, undersøgelses og idégenereringsfasen).

\section{Konstruktionsfasen}

Da eleverne havde tegnet deres modeller på papir og placeret højbedene, skulle de bygge deres model af højbedene på en træplade og male dem. Eleverne var meget fokuserede og opslugte i denne fase. De gjorde meget for, at det blev pænt, men samtidig havde de også nogle diskussioner fra forrige time om at lave det i et passende målestoksforhold. Dette var en sansekonkret opgave i den æstetiske virksomhedsform, og selvom det var et enkelt og på indholdsdelen lille element i den iterative designtilgang, var det en tidsmæssig tung opgave (se Figur 3, konstruktionsfasen).

\section{Idégenerering, undersøgelse og konstruktionsfasen}

Som den sidste del af forløbet skulle eleverne i gang med at designe selve systemet til at passe planterne. Først og fremmest blev der et stort fokus på et vandingssystem til planterne.

Læreren introducerede kort til sensorerne, og hvordan de tilsluttes. Han gav eleverne links til videoguides på nettet, som de så efterfølgende skulle justere efter deres krav. Der observeredes to tilgange: Grupper, som havde behov for at øve sig på at tilslutte og programmere sensorer. De benyttede sig derfor af en håndværksmæssig virksomhedsform, og grupper som kunne en del i forvejen, og som derfor havde en langt mere analytisk tilgang til arbejdet. I en gruppe blev blandt andet fugtighedssensorens grænseværdier undersøgt, og hvordan deres servomotor virkede. Derefter havde de også en meget analytisk, men også deltagende kommunikativ tilgang til programmeringsdelen, da de hele tiden diskuterede og talte programmeringen igennem, trin for trin. 


\section{Proesentationsfasen}

Afslutningsvis præsenterede grupperne deres produkter via en cafémodel. Her deltes grupperne i to, nogle var ude at høre på fremlæggelser, og andre blev tilbage og fremlagde. Derefter byttede de roller igen. Så eleverne vekslede mellem en receptiv og produktiv rolle i den kommunikative virksomhedsform. Eleverne havde her nogle fine dialoger omkring forskellige løsninger, og der var en stor erfaringsudveksling mellem grupperne (se Figur 3, præsentationsfasen).

\section{Virksomhedsformer - diskussionen/fund}

Når vi sammenholder virksomhedsformerne, som de fremkommer i måloversigt og læseplan, med det billede, der fremkommer i praksis, tegner der sig en slående forskel. Hvor der i læseplanen sås et tydeligt fokus på den analytiske virksomhedsform (og til dels den kommunikative), så viser det sig, at der i praksis er et samspil mellem alle fire virksomhedsformer, når læreren iscenesætter aktiviteter og eleverne arbejder med teknologiforståelse i de tre fag. Der er altså tale om, at virksomhedsformerne, som de er analyseret i læseplanenerne, ændrer sig og fortolkes i en retning af en mere flerdimensionel praksis.

Hvis styredokumenterne forstås som de valg, der er truffet i forhold til, hvilken faglighed der kommer til udtryk - og styredokumenterne, som van den Akker, Kuiper \& Hameyer (2003) har argumenteret for, foreskriver en didaktisk praksis - så er det interessant at undersøge nærmere, hvilken baggrund der er for denne forskel mellem oplægget i styredokumenterne og den didaktiske praksis med teknologiforståelse i de tre fag. Trods de forskellige historiske og erkendelsesmæssige grunde, der er knyttet til det, som de tre fag har til formål at undervise i, så kan vi sige, at når virksomhedsformerne sammenlignes fra læseplaner til praksis, finder vi ikke den store forskel mellem fagene. I alle tre fag har vi analyseret en forholdsvis ensporet tilgang til virksomhedsformerne i læseplanerne, mens der i praksis i alle tre fag findes et samspil mellem alle fire virksomhedsformer.

Med læseplanernes vægtning af de analytiske og kommunikative virksomhedsformer kan der argumenteres for, at de æstetiske og håndværksmæssige virksomhedsformer bliver midler til at komme frem til disse mål. I praksis så vi, at de håndværksmæssige og æstetiske virksomhedsformer blev et mål i sig selv, når eleverne eksempelvis skal fremstille smukke julefilm i matematikforløbet og ligeledes i danskforløbet, hvor den æstetiske erfaring får lov at spille en afgørende rolle som kilde til erkendelse. 


\section{Teknologibegreber i tillæg til læseplanen i de tre fag}

I vores bestræbelse på at se, hvorledes teknologibegreber og arbejdet med disse kommer til udtryk i spændet mellem styredokumenter og praksis både i fag og på tværs af fag, har vi foretaget en dokumentanalyse af målene og den efterfølgende læseplanstekst i de aktuelle trinforløb i tilføjelserne til læseplanerne til forsøgsprogrammet med teknologiforståelse i de tre fag (Undervisningsministeriet, 2018b,c,d). Målene og den efterfølgende læseplanstekst er analyseret i hvert fag, meningskondenseret og vurderet i forhold til de 7 teknologibegreber (Hansen, 2020b). Denne analyse på tværs af de tre fag tydeliggør, at der i de tre læseplaner er en overvægt af et instrumentelt teknologibegreb.

\section{Det instrumentelle teknologibegreb}

Det instrumentelle teknologibegreb forstås med Hansens (2020a) syv måder at begribe teknologi på med et fokus på, hvad teknologien gør for os, hvilke problemer den er med til at løse og hvordan vi tilpasser og effektiviserer teknologien.

Centralt i alle tre fag står arbejdet med digitalt design og designprocesser beskrevet under målene i læseplanerne. For alle tre fag gælder, at dette område knyttes til problemløsning:

Undervisningen skal fokusere på, at eleverne lærer at genkende og afkode forskellige problemfelter.... i realiseringen af ideen i form af fremstilling af et konkret digitalt artefakt, som andre kan anvende.

(fra dansk, Undervisningsministeriet, 2018b, s. 13)

Eleven kan identificere et problemfelt og rammesætte en designproces med henblik på design af digitale artefakter til gavn for individ og fællesskab.

(fra matematik, Undervisningsministeriet, 2018c, s. 10)

Eleven kan konstruere simple digitale artefakter, der udtrykker egne ideer ift. et natur/teknologi-fagligt problemfelt.

(fra N/T, Undervisningsministeriet, 2018d, s. 9)

Her knytter teknologien sig til innovationsmål og forstås funktionelt som elementer i problemløsning og udtrykker dermed en vægt på det instrumentelle teknologibegreb med fokus på, hvad teknologi kan gøre for os og hvilke problemer, den kan løse.

I matematikfagets læseplan har modelleringsaspektet en central plads, hvor der er specifikt fokus på, hvordan teknologien kan hjælpe 
med at opstille modeller, der kan tilpasses og effektiviseres: 'Eleven kan anvende digitale modeller i faglige sammenhænge og justere dem til nye behov' (fra Matematik, Undervisningsministeriet, 2018c, s. 11)

I læseplanen for natur/teknologi ses et fokus på at arbejde med algoritmer, der lægger vægt på, at eleverne kan stille og besvare typiske spørgsmål til en algoritmes virkemåde. Dette lægger op til et instrumentelt teknologibegreb, der ser på, hvad teknologier gør for os, og hvorledes teknologien kan tilpasses og effektiviseres.

I danskfaget er der i kompetenceområdet "Digital myndiggørelse" fokus på begrebet "redesign" (Undervisningsministeriet, 2018b, s. 14), som omhandler design af en alternativ løsning på baggrund af forudgående analyser og vurderinger. Redesign rummer samme aktiviteter som digital design og designprocesser, og vægter således også det instrumentelle teknologibegreb. I arbejdet med kompetenceområdet "Digital myndiggørelse" i dansk står også begrebet "intentionalitet" frem. I læseplanens brug af dette begreb peges der på, at digital myndiggørelse i dansk på 3. trinforløb handler om analyse og fortolkning af den intentionalitet (her forstået som hensigt), der er indlejret i relationen mellem designer og bruger i de menneskelige frembragte digitale artefakter. Med det overordnede fokus på intentionaliteten i produktionen af det digitale artefakt, og ikke i betydningen af artefaktet, understreges igen en instrumentel teknologiopfattelse, da intentionaliteten her forstås som en egenskab, der tillægges objektet teknologien.

\section{Det naturvidenskabelige teknologibegreb}

I matematik og natur/teknologi ser vi, at der fremtræder et betydeligt fokus på et naturvidenskabeligt teknologibegreb, hvor det fremhæves, at eleverne skal lære, hvordan teknologi teknisk set konstrueres.

Eleverne kan konstruere artefakter, der indeholder input fra sensorer (som fx lys, lyd, temperatur, bevægelse, ledningsevne og fugtighed) og output fra aktuatorer ( $\mathrm{x}$ i form af display (tekst og figurer), lys, lyd eller bevægelse.

(fra N/T, Undervisningsministeriet, 2018d, s. 9)

Eleven kan modificere, konstruere og fejlrette programmer. (fra Matematik, Undervisningsministeriet, 2018c, s. 11)

Ligesom der både i N/T og matematik lægges op til et naturvidenskabeligt teknologibegreb, når der er fokus på, at eleverne skal kunne anvende data og har viden om værktøjer til at håndtere dette med. 
Undervisningen tilrettelægges, så eleverne gennem konkret afprøvning bliver fortrolige med at undersøge digitale teknologier fra både natur/teknologi og elevernes hverdag for herigennem at få en forståelse for de digitale teknologiers forskellige komponenter. (fra N/T, Undervisningsministeriet, 2018d, s. 11).

Eleven kan identificere situationer i hverdagen, der kan oversættes til data og beskrive enkle situationer og procedurer fra hverdagen som algoritmer, rækkefølger og forgreninger.

(fra Matematik, Undervisningsministeriet, 2018c, s. 12)

Overordnet er det måske også naturligt, at læseplanen i både N/T og matematik netop lægger op til et naturvidenskabelig teknologibegreb, da det på mange måder er disse to fags grundsten.

\section{Øvrige anslag af teknologibegreber i læseplanerne}

Mens det for natur/teknologi gælder, at der i tilføjelsen til læseplanen for mellemtrinnet ikke er identificeret andre teknologibegreber end det instrumentelle og det naturvidenskabelige, så er der i dansk og matematik anslag, der peger mod et mere udvidet perspektiv.

I tilføjelsen til læseplanen for matematik beskrives det under overskriften Digital design og designprocesser også, at 'Eleven kan identificere et problemfelt og rammesætte en designproces med henblik på design af digitale artefakter til gavn for individ og fællesskab' (Undervisningsministeriet, 2018c, s. 10).

I tilføjelse til læseplanen i dansk for 3. trinforløb ses en overvægt af det instrumentelle teknologibegreb. Kun i forhold til én linje omkring opbygning af relevant fagsprog peger læseplansteksten i retning af et antropologisk-, humanistisk- og sociologisk teknologibegreb: 'Fagsproget bygges op om forhold som funktionalitet, etik, æstetik, brugspraksis, strukturelle eller organisatoriske forhold omkring anvendelsen af et digitalt artefakt' (fra Dansk, Undervisningsministeriet, 2018b, s. 14). I denne opbygning af fagsprog knyttes der derfor an til flere måder at begribe teknologi på end den instrumentelle. 


\section{Teknologibegreberne i praksis}

I dette afsnit anvender vi Hansens (2020b) syv teknologibegreber som analysegreb på de tre beskrevne praksisforløb i fagene dansk, matematik og natur/teknologi.

\section{Teknologibegreber i praksisforløbet i dansk}

Modsat analysen af styredokumenterne så vi i vores observation af praksisforløbet, at forløbet var tilrettelagt, hvor eleverne gennem designprocesser skulle designe et digitalt artefakt i form af en chatbot og dermed taler ind i det instrumentelle teknologibegreb - så blev der i forløbet iscenesat en række måder at begribe teknologi.

Først undersøgte eleverne deres egen og andres forforståelser i forhold til, hvad en robot er. I de diskussioner, det førte til i klassen, var der fokus på det instrumentelle: Hvad gør robotter for os, hvilke problemer er de med til at løse og på hvilke måder kompenserer og forstærker de, hvad vi mennesker kan og gør. Eleverne kom eksempelvis med bud som, at robotter kan blive brugt til at hjælpe folk ud af brændende huse, støvsuge, køre biler uden fører og slå græs.

I forlængelse heraf skiftede fokus dog til et etisk perspektiv og en teknologisk forestillingsevne med fokus på et humanistisk teknologibegreb, da eleverne forsøgte at forestille sig, hvordan det ville være og hvad det ville betyde, hvis læreren erstattes af en robot. Læreren spørger, om det vil være godt eller skidt, hvis læreren blev erstattet af en robot. Det er eleverne uenige om. De nævner fordele som, at robotten ikke glemmer noget, og at den kan vide alting. Andre peger på, at robotten netop ikke kan være et menneske. At den ikke kan drikke kaffe, hjælpe med konflikter og hjælpe når de er uvenner med deres forældre. En elev siger, at den ikke kan give ægte omsorg. Den har ingen følelser, men den kan lade som om (Dansk 5. kl., undersøgelsesfasen).

I observationen så eleverne to små film om særlige brug af robotter, der for eleverne kunne balancere mellem fantasi og virkelighed. Eleverne diskuterede blandt andet, om de kunne tænke sig sådan en virtuel ven/kæreste/kæledyr, som de så i den ene film. En elev udtrykte idéer til og fantasi om, hvad den kunne hjælpe hende med. Mens eleverne så en film om et hotel, der er styret af robotter, grinede de højt. Efterfølgende var eleverne optagede af, hvad der er robotternes begrænsninger i forhold til at drive hotel. En elev udtrykte, at hun ville foretrække et hotel med mennesker, da hun synes, det er upersonligt (Dansk 5. kl., filmfasen). Det gav anledning til at drøfte, hvorfor vi bruger begrebet “upersonligt". Med et fokus på, hvordan teknologien påvirker og forandrer, hvad vi mennesker kan, vil og gør vægtes et antropologisk teknologibegreb. Samtidig foranlediger begge de to film, at eleverne forholder sig både til teknologiens indflydelse på deres 
forestillingsevne og deres forestillingsevnes indflydelse på den teknologiske udvikling - og dermed begriber teknologien fra et humanistisk teknologibegreb. Desuden forholder eleverne sig til den teknologiske udviklings positive og negative virkninger, som beskrevet i det sociologiske teknologibegreb.

I praksisforløbet bringer lærerne således en flerdimensionel teknologiforståelse i spil. Trods forløbets udgangspunkt som et digitalt designforløb med en instrumentel forståelse, der har et snævert fokus på at producere et digitalt artefakt til løsning af et problem, så ses det, at der bringes både det antropologiske-, humanistiske- og sociologiske teknologibegreb i spil som grundlag for elevernes kritiske tænkning.

\section{Teknologibegreber i praksisforløbet i matematik}

Når vi kigger på det beskrevne observerede praksisforløb i matematik, er der tre forskellige teknologibegreber i spil.

Hovedfokus er på det naturvidenskabelige teknologibegreb, idet elevernes arbejde med kodning hjælper eleverne med en større forståelse for, hvordan kodning af små film teknisk set er konstrueret, og hvordan de selv kan konstruere sådanne små teknologiske film.

Også det instrumentelle teknologibegreb er tydeligt på spil, idet eleverne får en forståelse for, hvordan kodningsprogrammet Scratch rent faktisk kan bruges i mange forskellige sammenhænge. Et af målene var samtidig helt konkret, at eleverne skulle lære, at scratchkodning faktisk kan være et instrument i forhold til produktion af film.

Der er dog til dels også fokus på det humanistiske teknologibegreb i forhold til elevers æstetiske forestillinger, og hvordan disse spiller sammen med teknologien her i scratchkodningen. Eleverne brugte generelt meget tid på at få deres forestillinger om, hvordan filmen skulle være - for eksempel hvordan figurerne og baggrundene skulle spille sammen, da dette netop var en stor udfordring, og der var ofte ikke overensstemmelse mellem, hvad eleverne forestilledes sig, at figurerne skulle gøre rent æstetisk og så de teknologiske muligheder. En gruppe, der programmerede jule-egern, der bevæger sig rundt på et værelse, udtrykte både overraskelse over, at de nu rent praktisk kan lave en slags animationsfilm, men også at det ikke var så let at få det hele til at passe sammen i en større helhed, som også var æstetisk veludført. I praksis er der derved fokus på de tre teknologibegreber, det instrumentelle, det naturvidenskabelige og det humanistiske. 


\section{Teknologibegreber i praksisforløbet i natur/teknologi}

Når der ses på det afprøvede forløb i natur/teknologi omkring køkkenhaver, er der igen et meget stort fokus på det naturvidenskabelige teknologibegreb. Det handler om, hvilke grænseværdier, sensorerne har, og hvordan sensorerne tilsluttes og programmeres. I forhold til udvikling af teknologien, så arbejdede eleverne meget med programmeringen, hvor de hele tiden talte algoritmen igennem trin for trin. De undersøgte også de forskellige sensorer. De var interesseret i, hvilke grænseværdier fugtighedssensoren havde. De undersøgte værdien for, hvornår jorden var for tør, og hvornår den havde fået nok vand. De undersøgte ligeledes bevægelsessensor og, ikke mindst, hvor følsom og hvor lang en rækkevidde sensoren havde.

Det instrumentelle ses også særligt, når læreren præsenterede emnet og begrundede, at reguleringssystemet skulle bruges til deres køkkenhaver, som de skulle passe i forbindelse med et "jord til bord"projekt i hjemkundskab. Det instrumentelle teknologibegreb kom også til udtryk, når eleverne idégenerede, hvad deres reguleringssystem skulle kunne, som eksempelvis at måle fugtighed for derefter at aktivere en servomotor, som så kunne vande afgrøderne. Eksempelvis ville en gruppe elever give lys til afgrøderne, når afgrøderne ikke fik så meget sollys, og flere grupper fandt på en tyverialarm, hvis der kom tyve forbi - altså et fokus på, hvad teknologien kunne gøre for eleverne og deres afgrøder, for at de fik de bedst mulige vækstbetingelser og passede på afgrøderne, uden at de selv skulle ud og passe afgrøderne hele tiden.

Undervejs i projektet observeredes en dreng, som var frustreret, da han ikke kunne få sin fugtighedssensor til at virke:

Dreng: Hvorfor kan vi ik' bar gøre det normalt? Det virker ik 'det fucking lort

Hjoelpeloerer: Nej, ku det voere fordi man sku ' brug lidt hjoelp for at få det til at virke?

Dreng: Vi har fucking prøvet, vi har set videoen

Hjoelpeloerer: Hvad sagde videoen?... Ved I hvad... så synes jeg I har gjort det pisse godt

Dreng: Det er fandme så fucking dumt, at vi skal gøre det. Hvorfor kan vi $i k$ 'gøre det normalt og gå ud og vande normalt altså? Det er kraftedeme for dumt

Hjoelpeloerer: Det tcenker jeg, at I har snakket om, da I gik i gang med det projekt her. Hvorfor ku det gi mening at programmere noget til at hjoelpe jer?

Dreng: Det er spild af strøm

Hjoelpeloerer: Det er spild af strøm, synes du? 
Dreng: Ja. Vi kan bare gå ud at vande hver fucking dag eller sådan noget Hjoelpeloerer: Hmm, men hvad sker der, hvis jeg overvander planterne? Hvis jeg kommer til at give dem for meget vand?

Dreng: Så dør de

Hjoelpeloerer: Lige procis, så dør de faktisk

Dreng: Det sker ik så tit

Hjoelpeloerer: Nej, der skal meget til, men de kan faktisk godt

Dreng: Det har jeg sgu ik prøvet, selvom jeg har vandet 40 gange

(Natur/teknologi, 5. kl., undersøgelsesfasen)

Derefter gik hjælpelæreren i gang med at hjælpe drengen og hans gruppekammerat gennem programmeringen igen. Ovenstående citat vidner om, at hjælpelæreren argumenterer ud fra det instrumentelle teknologibegreb. Drengen var dog tydeligt utilfreds med svaret, og hans modsvar med, at teknologien brugte strøm, og at man bare kunne gå ud at vande, giver et indtryk af, at drengen ønskede at diskutere det gennem et politisk teknologibegreb. Bortset fra dette ene citat, arbejdede de kun med projektet gennem det naturvidenskabelige og instrumentelle teknologibegreb.

\section{Teknologibegreber - diskussion}

Med Hansens 7 teknologibegreber som ramme, så vi på, tværs af de tre fags læseplanstilføjelser, et gennemgribende instrumentelt teknologibegreb udtrykt. I de to STEM-fag, matematik og natur/teknologi, så vi desuden, ikke overraskende, et fokus på det naturfaglige teknologibegreb. Mere overraskende kan det virke, at vi ikke så spor af det humanistiske teknologibegreb i danskfagets tilføjelse til læseplanen.

I praksisforløbene så vi, at lærerne, især i dansk, men også i matematik, udfolder teknologibegrebet i bevægelsen fra styredokumenter til praksis, og dermed beriger teknologibegrebet og måden at arbejde med det på. Vi så i danskforløbet, hvordan der kom fokus på flere og andre måder at forholde sig til teknologi på - med anslag af både et antropologisk-, sociologisk og humanistisk teknologibegreb. I matematik arbejdes der ligeledes også med et humanistisk teknologibegreb. Med eksemplet fra natur/teknologi kan det diskuteres, om vi så, at et rent naturvidenskabeligt og instrumentelt teknologibegreb ikke giver mening for eleven, og at eleven udtrykker ønske om et bredere og mere politisk teknologibegreb end det, som der lægges op til i læseplanerne og i den konkrete undervisningspraksis. 


\section{Diskussion og konklusion}

Vi har i denne artikel været optagede af fagdidaktiske ytringer om teknologiforståelse i mødet med tre eksisterende fag. Vi har fokuseret på, hvilke valg der er truffet i forhold til, hvilken faglighed der kommer til syne i måder at begribe teknologi på og i måder at være virksom og arbejde med indholdet på i bevægelsen fra de diskursive ministerielle styredokumenter for forsøgsprojektet i henholdsvis natur \& teknologi, matematik og dansk og til praksis for eleverne i de tre fag.

Vi har vist, at der er et stort spænd imellem den måde, som styredokumenterne foreskriver en didaktisk praksis, og den måde som det praktiseres på, når det møder de tre fag på mellemtrinnet. Dette gælder både i forhold til måden at arbejde med teknologiforståelse på samt selve teknologibegrebet.

Når vi ser på tillæggene til læseplanerne for fagene dansk, matematik og natur/teknologi, fremkommer på tværs af fagene en beskrivelse, der lægger op til en primært analytisk virksomhedsform og et teknologibegreb, der udtrykkes meget i retning af en instrumentel og naturvidenskabelig forståelse. Denne beskrivelse kan vi ikke genfinde i praksis, hvor både virksomhedsformerne og teknologibegreber bliver langt mere flerdimensionelle. Dette sker på tværs af de tre fag, der har været genstand for denne undersøgelse.

I udfoldelsen fra de - i forhold til virksomhedsformer og teknologibegreber - ensrettede styredokument til praktisk undervisning er det dog også interessant, at den ensrettede beskrivelse foldes ud i forskellige retninger i de tre fag. Med Kroghs model (2011) til fagdidaktisk analyse af skolefag, hvor hun beskriver fag som tre forskellige praksisser i form af en retorisk praksis, som den måde faget beskrives på, en kulturel praksis, som den måde faget bedrives på og en teoretisk praksis, som den viden faget bygger på, så kan det diskuteres, om praksisforløbenes møde mellem fag og teknologiforståelsesfagligheden netop er et udtryk for en lydhørhed imellem de etablerede fags viden og praksis og læseplanens udtrykte teknologifaglighed, som skal integreres i fagene. Med Ellen Kroghs fagdidaktiske model in mente bliver det klart, at teknologiforståelse ikke skal integreres ensrettet i de tre fag, men netop møde fagets kulturelle praksis, virksomhedsformer, teoretiske praksis og naturlige teknologibegreber - og derigennem udvikle en lydhørhed i forhold til de historiske og erkendelsesmæssige grunde, der er knyttet til det, som faget har til formål at undervise i. Det vil være oplagt til videre undersøgelse fortsat at have fokus på, hvordan praksisforløb kan føre til en gensidig berigelse af både fag og teknologiforståelse. 


\section{Referencer}

Balsamo, A. (2005). Taking culture seriously: Educating and inspiring the technological imagination. Lokaliseret 5. august, 2021, på: http://www. designingculture.net/wordpress/wp-content/uploads/2010/o6/Balsamo_essay_ AcademicCommons.pdf.

Balsamo, A. (2011). Designing culture. Duke University Press.

Balslev, J, Riis, S. \& Hasse, C. (2021). En trojansk hest for den digitale sektor?, Folkeskolen-fagblad for undervisere, (5).

Brodersen, P. (1988). Æstetikken som redskab til kulturel afsøgning. Unge Poedagoger, (2), 4-12.

Brodersen, P. Hansen, T. I. \& Ziehe, T. (red.) (2019). Oplevelse, fordybelse og virkelyst noter til cestetik $i$ undervisningen (2. udg.) (84-122). Hans Reitzels Forlag.

Børne- og Undervisningsministeriet. (2019). Teknologiforståelse. EMU. Lokaliseret 5. august, 2021, på: https://emu.dk/grundskole/teknologiforstaaelse?b=t5

Børne- og Undervisningsministeriet (2020). Folles mål for faget natur/ teknologi. EMU. Lokaliseret 5. august, 2021, på: https://emu.dk/grundskole/ naturteknologi/faghaefte-faelles-maal-laeseplan-og-vejledning? $\mathrm{b}=\mathrm{t} 5$-t3o

Caeli, E. N. \& Bundsgaard, J. (2019). Datalogisk tænkning og teknologiforståelse i folkeskolen tur-retur. Tidsskriftet Loering Og Medier (LOM) 11(19). DOI: 10.7146/ lom.v11i19.110919

Caspersen, M. E., Iversen, O. S., Nielsen, M., Hjorth, A. \& Musaeus, L. H. (2018). Computational Thinking - hvorfor, hvad og hvordan. Efter opdrag fra Villum Fondens bestyrelse. Villum Fonden.

Christensen, O. (2020). Teknologi og forståelse - et intrikat mellemværende. Teknologiforståelse på skemaet, Unge Pcedagoger, (1), 15-24.

Christensen, O. (2021, 19. januar). Kritiske perspektiver på teknologiforståelse som fag. Folkeskolen.dk. Lokaliseret 5. august, 2021, på https://www.folkeskolen. dk/1863419/kritiske-perspektiver-paa-teknologiforstaaelse-som-fag

Dakers, J. (red.). (2014). New frontiers in technological literacy: Breaking with the past. Springer.

Dakers, J.R. (2006). Towards a Philosophy for Technology Education. I: J. R. Dakers (red.), Defining Technological Literacy Towards an Epistemological Framework (s. 145-158). Palgrave Macmillan US. DOI: 10.1057/97814.03983053

Dindler, C., Smith, R. C. \& Iversen, O. S. (2019). En designtilgang til teknologiforståelse. Dafolo.

Fangen, K. (2010). Deltagende Observasjon (2. udg.). Fagbokforlaget.

Fibiger, J., Hjorth, M., Lorentzen, R. F. \& Pasgaard, N. J. (2019). Digital myndiggørelse fra Kant over Dewey til teknologiforståelse i folkeskolen. Studier i loereruddannelse og -profession, 4(1), 56-76.

Flyvbjerg, B. (2006). Five misunderstandings about case-study research. Qualitative inquiry, 12 (2), 219-245. DOI: 10.1177/1077800405284363

Hanghøj, T., Misfeldt, M., Bundsgaard, J., Fougt, S. S. \& Hetmar, V. (2017). Hvad er scenariedidaktik? Aarhus Universitetsforlag. 
Hansen, T. I. (2020a). Æstetik og fordybelse. I: P. Brodersen, T. I. Hansen \& T. Ziehe (red.), Oplevelse, fordybelse og virkelyst - noter til cestetik i undervisningen (2. udg.) (s. 84-122). Hans Reitzels Forlag.

Hansen, T. I. (2020b). Teknologiforståelse. I: P. Brodersen (red.), Didaktisk opslagsbog (s. 281-286). Hans Reitzels Forlag.

Hansen, T. I. (2020c). Teknologiforståelse som praktisk klogskab - om variation og virksomhedsformer i teknologiforståelse som fag. Unge Pcedagoger, (1), 25-35.

Heidegger, M (1999) Spørgsmålet om teknikken og andre skrifter. I: M. Goll \& M. Zahavi (red.), Spørgsmålet om Teknikken og Andre Skrifter (s. 36-65). Samlerens Bogklub.

Hsieh, H. F. \& Shannon, S. E. (2005). Three approaches to qualitative content analysis. Qualitative health research, 15(9), 1277-1288.

DOI: 10.1177/1049732305276687

Ihde, D. (1998). Philosophy of Technology: An Introduction. Philosophical Books.

Ihde, D. (2002). Bodies in technology (Vol. 5). University of Minnesota Press.

Krogh, E. (2011). Undersøgelser af fag i et fagdidaktisk perspektiv. Cursiv, 7 -Sammenlignende fagdidaktik, 33-49.

Matthews, J. \& Cramer, E. P. (2008). Using technology to enhance qualitative research with hidden populations. Qualitative Report, 13(2), 301-315. DOI: 10.46743/2160-3715/2008.1600

McHugh, M. L. (2012). Interrater reliability: the kappa statistic. Biochemia medica, 22(3), 276-282. DOI:10.11613/BM.2012.031

Naur, P. (1954). Elektronregnemaskinerne og hjernen. Perspektiv, 1(7), 42-46.

Nørgård, R. T. (2020): Teknologifantasi. KvaN 117 - Teknologiforståelse.

Rasch-Christensen, A. \& Hansen, T. I. (2021, 15. marts). Teknologiforståelse skal dreje sig om digital myndiggørelse. Skolemonitor.dk. Lokaliseret 5. august, 2021, på: https://skolemonitor.dk/debat/art8132924/Teknologiforst\%C3\%A5elsen-skaldreje-sig-om-digital-myndigg\% $\mathrm{C} 3 \%$ B8relse

Selwyn, N. (2010). Looking beyond learning: notes towards the critical study of educational technology. Journal of Computer Assisted Learning, 26(1), 65-73. DOI: 10.1111/j.1365-2729.2009.00338.x

Schnedler, C.J. \& Seeberg, T. (1998). Den praktisk musiske dimension i undervisningen: forløb og erfaringer: En introduktion. Undervisningsministeriet, Folkeskoleafdelingen.

Stake, R. E. (2013). Multiple case study analysis. Guilford Press.

Tamborg, A. L., Dreyøe, J. M. \& Fougt, S. S. (2018). Digital literacy - a qualitative systematic review. Tidsskriftet Loering Og Medier (LOM), 11(19), 29. DOI: 10.7146/ lom.v11i19.103472

Undervisningsministeriet. (2018a). Foelles mål. Teknologiforståelse. Undervisningsministeriet. Lokaliseret 5. august, 2021, på: https://www.uvm.dk/-/ media/filer/uvm/aktuelt/pdf18/181221-maaloversigt-teknologiforstaaelse.pdf

Undervisningsministeriet. (2018b). Tilføjelse til loeseplan i dansk. Forsøgsprogrammet med teknologiforståelse. Undervisningsministeriet.

Undervisningsministeriet. (2018c). Tilføjelse til loeseplan i matematik. Forsøgsprogrammet med teknologiforståelse. Undervisningsministeriet. 
Undervisningsministeriet. (2018d). Tilføjelse til loeseplan i natur/teknologi Forsøgsprogrammet med teknologiforståelse. Undervisningsministeriet van den Akker, J. J., Kuiper, W. \& Hameyer, U. (red.). (2003). Curriculum landscapes and trends (s. 1-10). Kluwer Academic Publishers.

\section{Appendix}

Kodning af læseplaner i forhold til virksomhedsformer.

Operationalisering af virksomhedsformer (beskrivende, men ikke udtømmende liste af operationaliseringer).

Fstetisk: Oplevelse, udtryk, sanse, føle, fantasi og forestillinger
Kommunikativ: Kommunikativ i relation til indhold, deltagelse, fremstilling, fremlæggelser, fortælle, reflektere, diskutere

Analytisk: opløse, opdele, modellering, demonstration, forståelse, dele og helhed, begrebsligt, skelne, beskrive forklare
Håndværksmæssig: Træning, øvelser fagspecifikke færdigheder, øve sig på afgrænsede aktiviteter
Kategorier til kodning af loeseplanerne for virksomhedsformer i de enkelte fag.

\begin{tabular}{l|l} 
Kode & Beskrivelse \\
\hline 0 & Ikke tilstede \\
\hline 1 & $\begin{array}{l}\text { Tilstede i mindre grad - sammen med en eller flere virksomhedsformer (1-2 } \\
\text { sætninger med tilstedeværelse af virksomhedsformer }\end{array}$ \\
\hline 2 & $\begin{array}{l}\text { Tilstede i større grad - sammen med en eller flere andre virksomhedsformer } \\
\text { (mere end } 2 \text { sætninger med tilstedeværelse af vorksomhedsformer) }\end{array}$ \\
\hline 3 & Dominerende - den eneste virksomhedsform \\
\hline
\end{tabular}

